\title{
Anne-Marie Brady, Marketing Dictatorship: Propaganda and Thought Work in Contemporary China
}

Marie-Eve Reny

\section{OpenEdition}

\section{Journals}

Édition électronique

URL : http://journals.openedition.org/chinaperspectives/5089

DOI : 10.4000/chinaperspectives.5089

ISSN : 1996-4617

Éditeur

Centre d'étude français sur la Chine contemporaine

Édition imprimée

Date de publication : 21 avril 2010

ISSN : 2070-3449

\section{Référence électronique}

Marie-Eve Reny, «Anne-Marie Brady, Marketing Dictatorship: Propaganda and Thought Work in Contemporary China », China Perspectives [En ligne], 2010/1 | 2010, mis en ligne le 22 avril 2010, consulté le 21 septembre 2020. URL : http://journals.openedition.org/chinaperspectives/5089; DOI : https://doi.org/10.4000/chinaperspectives.5089

Ce document a été généré automatiquement le 21 septembre 2020.

(c) All rights reserved 


\title{
Anne-Marie Brady, Marketing Dictatorship: Propaganda and Thought Work in Contemporary China
}

\author{
Marie-Eve Reny
}

1 Anne-Marie Brady, Marketing Dictatorship: Propaganda and Thought Work in Contemporary China, Lanham, Rowman and Littlefield, 2008, 232 pp.

2 In Marketing Dictatorship, Anne-Marie Brady explores the role of political propaganda and thought work in post-1989 China, which she claims "have become the very life blood [...] of the Party-State" (p. 1). Although those tools were also crucial for shaping public opinion and protecting the state's image under Mao, the author argues that the CCP "has transformed itself from a revolutionary party holding power by right of ideology to that of a political party in power (zhizheng dang)" (p. 2). Underlying the latter is a logic aiming at ensuring the CCP's ongoing legitimacy to rule, with greater emphasis on persuasion than repression. Mindful of the lessons of the Soviet Union, the Chinese leadership realised that force could only constitute a short-term solution, and that long-term control required a "methodology of mass persuasion" (p. 71). As such, China's leaders have used Western mass communications theory to master the methods of "engineering consent" (p. 3). While they've exploited the benefits of PR and the Internet, they've also developed software, introduced filters, and relied upon a wellinformed police force to manage the "side effects" of information communication technologies (p. 145). Brady contrasts these modern propaganda strategies with those prevalent under Mao, including mass organisations (qunzhong zuzhi).

3 Furthermore, the content of public discourse between those two eras differs significantly. While downplaying Marxism-Leninism, some of the key themes that the central government has stressed in the past 20 years are economic liberalism, nationalism, and "selective anti-foreignism" (p. 3). Economic liberalism meant greater press freedom as far as reporting economy-related news was concerned. Nationalism 
was accompanied by the spread of patriotic education sites such as memorials and museums (p. 50), as well as pressure on journalists to publicly stress that Taiwan is a province of China (p. 103). Similarly, news about ethno-nationalist mobilisation in other parts of the world was censored for fear of inciting local ethno-nationalist groups to challenge efforts aimed at consolidating a Chinese national identity (p. 52). "Selective anti-foreignism" took the form of explicit critiques of the system of mass persuasion in modern democratic societies (e.g., Noam Chomsky's books became references in China's schools of journalism), and censorship of foreign information that could compromise the country's image. The Central Propaganda Department established simple norms and objectives for public discourse: "think positive" (p. 95), "no bad news during holiday periods or sensitive dates" (p. 96), avoid raising problems that are hard to solve, speak of the economy, "demonize the United States" (p. 98), refrain from "promot[ing] the views of the enemy" (p. 99), and selectively report international news.

Brady's book is groundbreaking in two ways. First, it provides a comprehensive institutional account of the inner workings of the propaganda system. It explains who is responsible for censoring what, and how organisations relate to each other. Additionally, it sheds light on who in that system gained or lost influence after 1989. For instance, while "the Propaganda Department of the General Political Office of the PLA ha[d] a history of making independent decisions in propaganda matters" (p. 26), since the 1990s, some important PLA figures have been punished for deviating from the Central Propaganda Department's line (p. 27).

5 Second, Brady's book helps fill an important gap in the literature on ideology and propaganda in China by situating the leadership's censorship methods within the context of thought work strategies in other non-democratic and democratic societies. For instance, Brady emphasises that the party-state has drawn lessons from the propaganda mistakes of the Soviet Union. In the eyes of Beijing, Gorbachev's move from glasnost in 1985 to an attempt to re-impose media censorship in 1991 was a recipe for disaster. Similarly, Chinese think tanks have analysed the rise and fall of long-term one-party states in countries such as Mexico, Japan, and Singapore (p. 182), and the potential role of propaganda in the latter. Finally, among other examples, the CCP has learned from the success of the United States in ensuring "patriotic education and respect for the flag" (p. 180), and has sought to apply similar methods for those same purposes.

6 Despite its significant contributions, the book has three weaknesses. First, beyond specific examples of topics or events that were completely banned for public discussion (e.g., the outbreak of SARS in 2003) or promoted by the CCP (e.g., the US bombing of Chinese Embassy in Belgrade in 1999), there is no specific framework analysing the reasons for variance in the content of propaganda. Why are some matters constructed as threatening to the image of the CCP, and others not? How are the boundaries drawn between problems that can be openly discussed and those that cannot be?

7 Second, while Brady suggests that propaganda has played a major role in ensuring regime resilience in post-1989 China, the author does not articulate the mechanisms linking effective propaganda and the continuity of CCP rule. More precisely, Brady's analysis offers no systematic explanation of the impact of thought work on public minds. Doing so would have required moving away from an exclusive focus on the propaganda system as the unit of analysis, and tracing the mechanisms through which 
formal institutions mould ideas, norms, and opinions within society, and/or the ways in which society reacts to institutions. The reader is thus left thinking that Brady is inferring the effectiveness of propaganda based on the institutional coherence of its apparatus. Existent studies suggest that the latter does not have a uniform effect on public minds, as implicitly suggested in Brady's analysis. Béja provides an interesting account of the loopholes and contradictions in the propaganda system. He emphasises that a number of intellectuals, including Ding Dong and Li Hui, have developed alternative interpretations of the history of the People's Republic that are sold today by official publishers in China. ${ }^{1}$ In a similar vein, Pils (2007) stresses that in recent years, many mainland lawyers have dedicated their work to the defence of legal rights (weiquan) and to the rectification of historical injustices, ${ }^{2}$ hence challenging the authorities' own conception of rights and interpretation of history.

A potential way to address the effects of the propaganda system on public minds more explicitly could have been to pay closer attention to the significant role of education as a vehicle for thought work. The author unfortunately obscures much of this.

9 Finally, Brady could have situated the "propaganda" factor in the broader context of academic debates about the causes of autocratic regime resilience, in China and elsewhere. To what extent is propaganda more important than other factors stressed in the regime literature? How can it complement existent studies?

Anne-Marie Brady's Marketing Dictatorship nonetheless remains a significant contribution that speaks to a wide range of studies, including those on Chinese nationalism and autocratic resilience. As yet, it is the first attempt to provide a comprehensive account of the institutional complexity of the propaganda apparatus in post-1989 mainland China.

${ }^{1}$ Jean-Philippe Béja, "Forbidden Memory, Unwritten History: The Difficulty of Structuring an Opposition Movement in the PRC," China Perspectives, No. 4, 2007, p. 98. ${ }^{2}$ Eva Pils, "The Persistent Memory of Historic Wrongs in China: A Discussion of Demands for "Reappraisal," China Perspectives, No. 4, 2007, p. 99.

\section{NOTES}

${ }^{1}$ Jean-Philippe Béja, "Forbidden Memory, Unwritten History: The Difficulty of Structuring an Opposition Movement in the PRC," China Perspectives, No. 4, 2007, p. 98. ${ }^{2}$ Eva Pils, "The Persistent Memory of Historic Wrongs in China: A Discussion of Demands for 'Reappraisal," China Perspectives, No. 4, 2007, p. 99. 